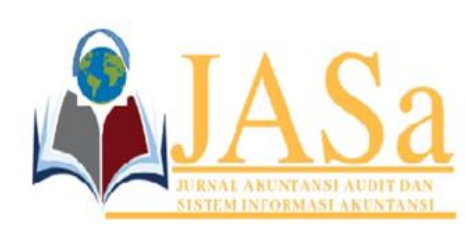

JASa (Jurnal Akuntansi, Audit dan Sistem Informasi Akuntansi)

Vol. 5 No.1/ April 2021

ISSN 2550-0732 print / ISSN 2655-8319 online

DOI;10.36555/jasa.v5i1.1511

\title{
E-GOVERNMENT INTEGRATED E-AUDIT SYSTEM : DESIGN AND ANALYSIS IN THE INTERNAL AUDIT UNIT OF THE INDONESIAN GOVERNMENT (APIP)
}

\author{
Deni Hidayat \\ Universitas Padjadjaran, Indonesia \\ deni.hidayat86@gmail.com
}

\begin{abstract}
The Government Internal Supervisory Unit (APIP) is a work unit that has the task of carrying out internal supervision in the government environment. The development of the Electronic Based Government System (SPBE) has changed the business processes that occur in government governance from manual to digital form. The implementation of SPBE in government activities has resulted in a lot of data or documents in digital form, but on the other hand the process of implementing audit activities carried out by APIP is currently still being carried out manually, has not made much use of digital data or documents, and has not been supported by the use of an integrated audit management information system. This study aims to design an integrated electronic-based audit system model (e-Audit) with SPBE in the APIP environment. The research method used is qualitative with a case study approach in one of the Inspectorates of Non-Ministry Government Institutions, the result of this research is an integrated e-audit system model which is described in a System Context Diagram, Data Flow Diagram (DFD) and Entity Relationship Diagram (ERD).
\end{abstract}

Keywords: Design; System; E-Audit; SPBE; APIP

\section{INTRODUCTION}

Advances in Information and Communication Technology (ICT) in the era of the industrial revolution 4.0 had a major impact on changes in business processes and the workings of an organization, be it private sector organizations (private) and public sector organizations (government). In the government sector, the implementation of $e$ government in Indonesia is increasing day by day. This is based on the results of a survey conducted by the Department of Economic and Social Affairs (United Nation) on the e-Government Development Index (EDGI) where Indonesia is in 88th place out of 193 countries surveyed in 2020. This shows that Indonesia has increased 19 rankings from the survey conducted in 2018 (Department of Economic and Social Affairs, 2020).

The increased use of the Electronic Based Government System (SPBE) in Indonesia is reflected in the implementation of various new applications in the government sector. Some of the applications include, from the planning aspect, the KRISNA (Collaboration Planning and Budget Information) e-planning application issued by the Ministry of National Development Planning / BAPPENAS. Then from the aspect of e-budgeting budget planning, there is the Satu-DJA application (Integrated Application System of the Directorate General of Budget) and the Online Ministry / Institution Budget Work Plan (RKA K / L) application issued by the Ministry of Finance. Also in terms of budget execution there are many applications including the GPP-application (Application for Employee Salary Management), the SAS Application (Work Unit Application System

Submitted: September 12, 2020; Accepted: September 12, 2020; Revised: December 12, 2020; Published: April 24, 2021; Website: http://journalfeb.unla.ac.id/index.php/jasa 


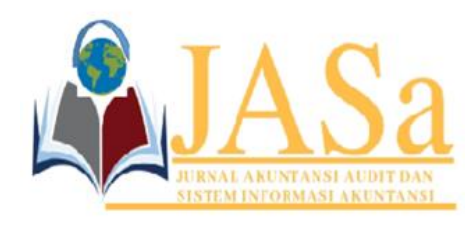

\author{
JASa (Jurnal Akuntansi, Audit dan Sistem Informasi Akuntansi) \\ Vol. 5 No.1/ April 2021 \\ ISSN 2550-0732 print / ISSN 2655-8319 online \\ DOI;10.36555/jasa.v5i1.1511
}

is used for the implementation of central government work unit activities), also in terms of accounting reporting systems there is an online e-REKON \& LK application. as an integrated financial management information system, and also in terms of procurement of goods and services, the e-Procurement Electronic Procurement System (SPSE) is issued by the Government Procurement Policy Institute (LKPP). In addition, within the organization's organization, there are several information systems used for operational activities, such as official travel information systems, personnel information systems, and employee performance information systems.

The Government Internal Auditor (APIP) has an interest in increasing the use of information technology in the application of this SPBE, especially in terms of security, confidentiality, data validity and integrity, as well as the quality of information used for decision making and report presentation. In addition, the output produced by the SPBE can be used as evidence in conducting audits. Statement on Auditing Standards (SAS) no. 94 (American Institute of Certified Public Accountants, 2001) in an environment that has run a computerized system it is advisable to assign an information systems auditor to conduct an information technology audit. If audits are carried out on entities that have run a complex information system, the information system audience will be able to increase the sources of evidence obtained (Kristian \& Imelda, 2017).

APIP is an organization / government work unit that is formed and has the task of carrying out internal supervision of the implementation of duties and functions of Government Agencies, including accountability for state finances, and fostering the implementation of the Government Internal Control System (SPIP). In carrying out its role as an internal supervisor, APIP carries out auditing, monitoring and other supervisory activities on the implementation of organizational duties and functions in order to provide sufficient confidence that the activities carried out have met the criteria with effective and efficient implementation in realizing good government governance. (Government Regulation No.60 of 2008 concerning Government Internal Control Systems, 2008).

The development of the e-Government system is marked by the emergence of many applications in the implementation of government systems, both in the financial system and in organizational operational activities. This has resulted in quite a lot of electronic data, where this data can be used as a source of data in conducting audits. The E-Audit system by utilizing Information Technology (IT) is considered to be able to facilitate the collection and analysis of audit evidence to support the implementation of a more effective and efficient examination (Karimah, 2018).

However, the problem that arises is the spread of applications in each independent entity that have not been integrated with each other and also in the current audit implementation, most of them are still based on manual data sources (paper based), besides that the management of audit activities is still not recorded properly. good and not yet documented into an electronic system. This makes the audit activity ineffective and inefficient. hence an electronic-based inspection / audit approach and an audit management system are needed that can be integrated with the various SPBE systems that have been built. This is to accelerate and increase the effectiveness and efficiency in the implementation of audits in the APIP environment. The implementation of e-Audit

Submitted: September 12, 2020; Accepted: September 12, 2020; Revised: December 12, 2020; Published: April 24, 2021; Website: http://journalfeb.unla.ac.id/index.php/jasa 


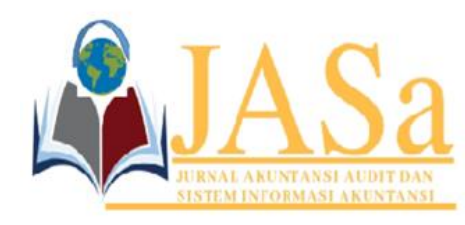

\author{
JASa (Jurnal Akuntansi, Audit dan Sistem Informasi Akuntansi) \\ Vol. 5 No.1/ April 2021 \\ ISSN 2550-0732 print / ISSN 2655-8319 online \\ DOI;10.36555/jasa.v5i1.1511
}

with the main features in it is considered effective for use in the audit process of local government finances (Mubiroh, 2019). In addition, according to (Tarippudin, 2014) EAudit is able to improve audit quality and efficiency in the inspection process.

The audit activities carried out by APIP include performance audits and audits with specific objectives. Performance audit has the definition of an audit of the management of state finances and the implementation of the duties and functions of government agencies which consist of aspects of efficiency, efficiency and effectiveness. Meanwhile, an audit with a specific purpose has a definition of an audit that is carried out with a specific purpose outside of financial audits and performance audits (Government Regulation No.60 of 2008 concerning Government Internal Control Systems, 2008).

In carrying out their duties, auditors are required to be professional in using their expertise carefully and thoroughly (due professional care) and carry out prudently. The implementation of professional due care and prudent care is a form of the auditor's responsibility to pay attention to audit standards and to consider the use of technologybased audits and other data analysis techniques (Indonesian Government Internal Audit Standards, 2013).

(Arens, A. A and Loebecke, JK, 1997) "Auditing is the process of collecting and evaluating audit evidence material about measurable information about an economic entity by a competent and independent person to determine and report the conformity of information to the criteria. predetermined criteria ". (Mulyadi, 2002) Auditing can be classified into three groups, namely the General Financial Statement Audit, Compliance Audit, Operational / Management Audit. (Gondodiyoto, 2003) There are three method approaches in conducting audits using computer technology, including: Auditing Around The Computer This method requires the auditor to test the input and output controls generated by the transaction process, then compare them with the auditor's manual calculations. Auditing Through The Compute This method requires auditors not only to test input and output, but go deeper into testing the flow and accuracy of the program including program language, application design, and other things. Auditing With Compute This type of audit is carried out by using a computer and software approach to automating the audit procedures. This method can be useful in a substantive test of the company's transaction data.

Electronic audit (e-Audit) is a systematic, independent and documented process for obtaining audit evidence through electronic means to determine the level of conformity with audit criteria. According to the Florida Department of Revenue Audit, electronic, or e-Auditing, is a computer-assisted audit that uses electronic records to complete all or part of an audit. If you use a computer to record your business activities and maintain the data electronically, it will allow you to conduct an electronic audit.

(Presidential Regulation Number 95 of 2018 concerning Electronic Based Government Systems, 2018) In the Presidential Regulation of the Republic of Indonesia Number 95 of 2018 concerning Electronic Based Government Systems (SPBE) it is explained that SPBE is a government administration that utilizes information and communication technology to provide services to users SPBE. Interrelated business processes are compiled in an integrated manner to support the development or development of SPBE applications and integrated SPBE services. Integration of the

Submitted: September 12, 2020; Accepted: September 12, 2020; Revised: December 12, 2020; Published: April 24, 2021; Website: http://journalfeb.unla.ac.id/index.php/jasa 


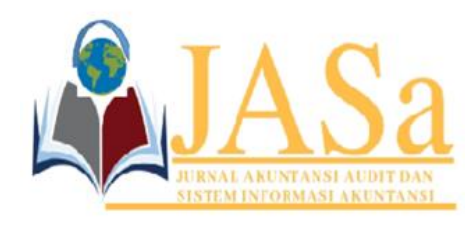

\author{
JASa (Jurnal Akuntansi, Audit dan Sistem Informasi Akuntansi) \\ Vol. 5 No.1/ April 2021 \\ ISSN 2550-0732 print / ISSN 2655-8319 online \\ DOI;10.36555/jasa.v5i1.1511
}

planning, budgeting, procurement of government goods and services, performance accountability, and monitoring and evaluation business processes is implemented through the integration of SPBE services which include budgeting services, procurement services, performance accountability services, and monitoring and evaluation services. SPBE service integration is carried out through: Share data on planning, budgeting, procurement of government goods and services, performance accountability, and monitoring and evaluation. Operation of an integrated database for data sharing. implementing an integrated planning, budgeting, procurement, performance accountability, and monitoring and evaluation application system.

Application Programming Interface (API) technology is an application technology that functions as a service provider for connecting data information between electronic systems using web service technology. (Redhat, 2020) According to RedHat, a global information technology company defines an API as a set of rules and protocols for building and integrating application software. With the use of API technology, it is possible to integrate data between systems that are scattered in each entity into one integrated system.

In the application system development process, there are many methods that can be used, including the System Development Life Cycle (SDLC) method, the Waterfall method, the Prototyping method, the Rapid Application Development (RAD) method, the Spiral method, the Object-Oriented Technology method, and the FAST method. To fulfill the need for information system development, the FAST method is used here because of its ability to support rapid application development. FAST is also called agile modeling, and it is developed from a combination of references and methodological best practices. In addition, it supports other techniques, including structured systems analysis, information engineering, and object-oriented analysis and design (Whitten, J. L., \& and Bentley, L. D., 2007). The Whitten version of the FAST methodology used in this study goes through the following stages: Scope Definition. The scope definition has two purposes: first, to determine whether the problem found is important, and if so, second, can it be used to determine the size and scope, vision, mission, constraints, participating parties, budget, and project schedule to be solved. Problem Analysis. This stage explores the existing system and analyzes the problem in the context of a broader understanding to allow the problem to be analyzed, as well as to analyze opportunities and constraints. Requirement Analysis. It sets out the business requirements that must be met through the offered system. Logical Design Phase. Here, the business requirements that the system must meet for data, processes and displays that ensure usability, reliability, completeness, performance.

The purpose of this research is to design an e-Audit system within a government internal control unit that is able to be integrated with SPBE.

Submitted: September 12, 2020; Accepted: September 12, 2020; Revised: December 12, 2020; Published: April 24, 2021; Website: http://journalfeb.unla.ac.id/index.php/jasa 


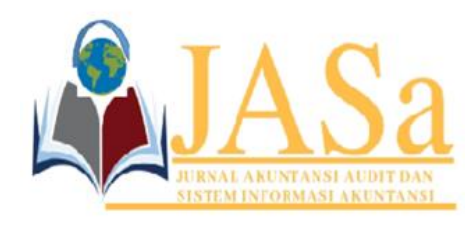

\author{
JASa (Jurnal Akuntansi, Audit dan Sistem Informasi Akuntansi) \\ Vol. 5 No.1/ April 2021 \\ ISSN 2550-0732 print / ISSN 2655-8319 online \\ DOI;10.36555/jasa.v5i1.1511
}

\begin{abstract}
METHODS
The method used in this research is a qualitative method with a single case study approach, and which is used as the unit of analysis is the Government Internal Supervisory Unit in one of the Non-Ministry Government Institutions (LPNK) located in Jakarta. The case study approach was chosen because it discusses the problem in depth and in detail to get a solution to the problem.

There are two types of data used in this study, firstly primary data, namely data from interviews and field observations, and secondary data used in the form of research literature, books and electronic articles which are in line and can assist the research process.

To collect data, researchers interviewed the Inspector as head of APIP with a number of senior and junior auditors, and made preliminary observations, and studied unit analysis documents related to audit documents. The researcher then analyzes and identifies potential problems from the issue of audit implementation with the PIECES model approach (Performance, Information, Economics, Efficiency, and Services). According to Giorgini (2003) this PIECES framework can help to identify problems to be solved and their urgency, the PIECES approach This is a stage of the FAST method used to get the expected improvements in the analysis stage.

In this study, the analysis and system design were carried out using the FAST (Framework for the Application of Systems Technique) method. This method has eight stages, namely: Scope Definition, Problem Analysis, Requirements Analysis, Logical Design, Decision Analysis, Physical Design and Integration, Construction and Testing, and Installation and Delivery. Of the eight stages, this study only uses four stages, namely Scope Definition, Problem Analysis, Requirements Analysis, and Logical Design.
\end{abstract}

\title{
RESULTS AND DISCUSSION
}

The Government Internal Supervisory Unit (APIP) / Inspectorate is a work unit or division assigned the task of carrying out internal supervision within government agencies to ensure that the government internal control system is carried out effectively and efficiently. There are several activities carried out in order to carry out these tasks, one of which is to carry out internal audits in work units within the organization. The audits that are carried out include financial audits, compliance audits, operational audits, performance audits, and audits with specific objectives that are more specific in scope.

The position of the APIP / Inspectorate based on the coordination line is directly under the leadership / head of the institution, but administratively under the main secretary. The object of the inspection (audite) which is the scope of the inspection / audit of the inspectorate is all work units within the institution / organization.

Submitted: September 12, 2020; Accepted: September 12, 2020; Revised: December 12, 2020; Published: April 24, 2021; Website: http://journalfeb.unla.ac.id/index.php/iasa 


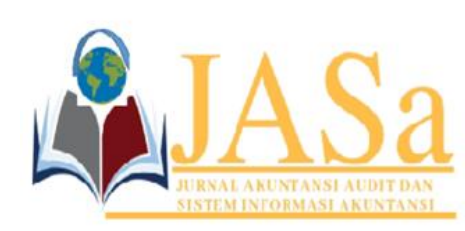

JASa (Jurnal Akuntansi, Audit dan Sistem Informasi Akuntansi)

Vol. 5 No.1/ April 2021

ISSN 2550-0732 print / ISSN 2655-8319 online

DOI; $10.36555 /$ jasa.v5i1.1511

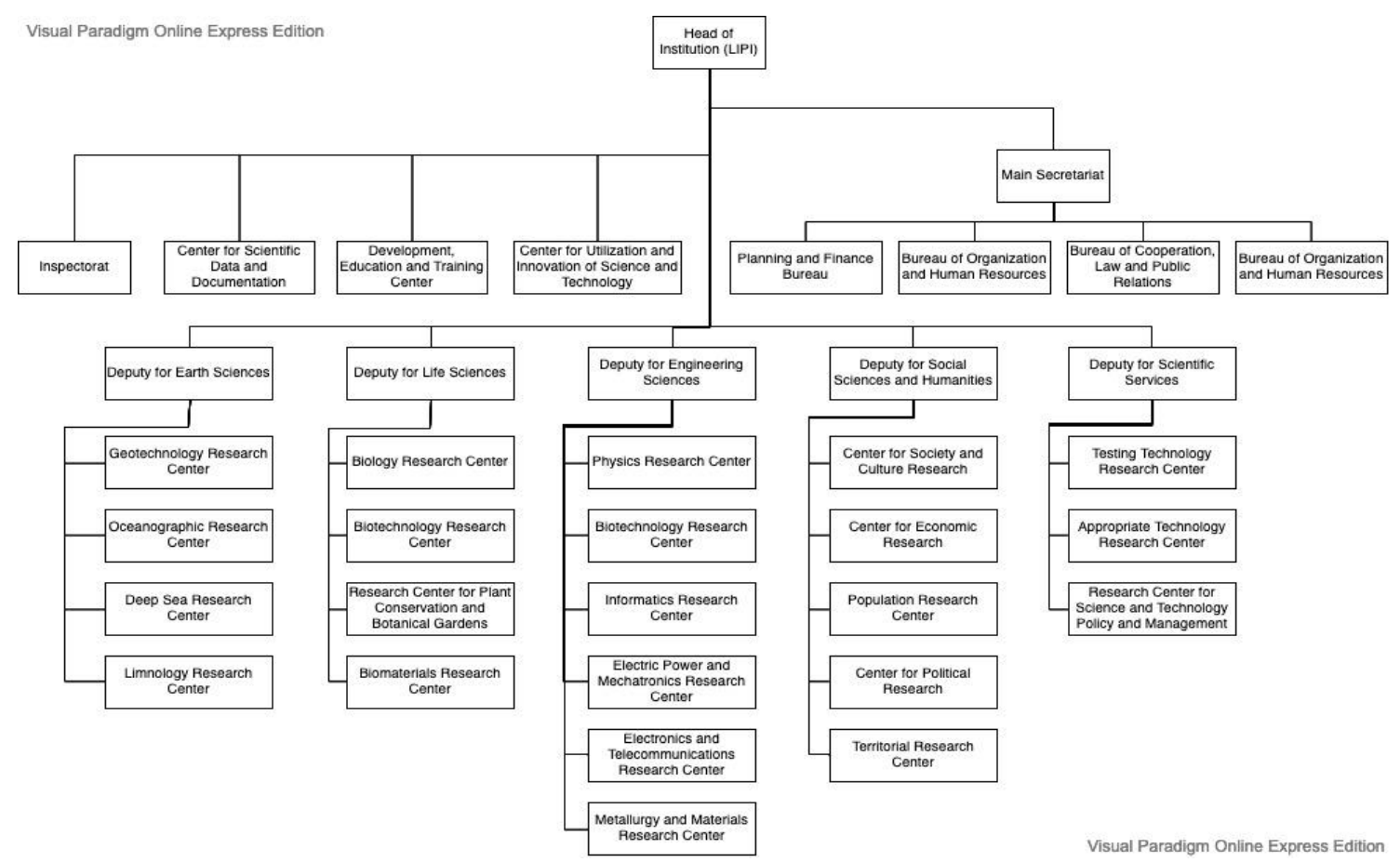

Figure 1. Organizational Structure of the Indonesian Institute of Sciences

Source: Head of LIPI Regulation No. 1 of 2019

In the implementation of internal audit activities, APIP implements it based on the Standard Operating Procedure (SOP) that has been made. There are two major stages in the implementation of the audit, namely the administrative stage and the technical stage. The administrative stage covers the preparation of the audit team members and the determination of the object of the examination (audite). Meanwhile, for the technical implementation of the audit that runs at the Inspectorate of LIPI, there are 4 steps as follows: Preliminary Audit (3 days) The preliminary audit aims to collect information, review the regulations, provisions and laws relating to the activities being audited, and analyze the information obtained in order to identify potential points of weakness.

a. Preliminary Audit Stages

- The audit begins with the Auditor examining the organizational structure, the place of the work unit, their relationship with other units, the assignment of functions and responsibilities.

- Auditors track the correct activities by full flow charting or by following selected documents continuously at key points of control.

- The auditor will review the policies and procedures that apply to the unit to be audited.

- The auditor conducts tests on the Internal Control System (SPI) with a view to further solidifying the tentative audit objectives that have been identified during the audit preparation stage. SPI testing aims to assess the effectiveness of management control and better identify any weaknesses so that it can be ascertained whether a Tentative Audit Objective (TAO) can be continued at the advanced inspection stage or not.

Submitted: September 12, 2020; Accepted: September 12, 2020; Revised: December 12, 2020; Published: April 24, 2021; Website: http://journalfeb.unla.ac.id/index.php/jasa 


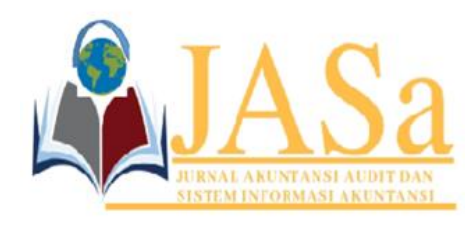

\author{
JASa (Jurnal Akuntansi, Audit dan Sistem Informasi Akuntansi) \\ Vol. 5 No.1/ April 2021 \\ ISSN 2550-0732 print / ISSN 2655-8319 online \\ DOI;10.36555/jasa.v5i1.1511
}

\title{
b. Follow-up Audit (15 days)
}

The follow-up examination aims to obtain sufficient evidence to support the definitive objective of the examination that has been obtained during the testing and review phase of the SPI. At this stage the Auditor selects definitive goals, then collects relevant, material and competent evidence, leading to a conclusion regarding the audit objectives concerned. The follow-up audit stage is directed at 4 targets:

1) Background information relating to the examination.

2) The final result expected.

3) The audit procedures required to complete the work.

4) Special instructions if needed.

Evidence obtained here includes evidence obtained at an earlier stage. Evidence gathered from the detailed audit results is summarized in sufficient working paper to support the conclusion of the audit report. Based on the evidence summarized in the working paper, a work report on the audit results is made, including conclusions and recommendations.

The evidence obtained must meet the quality and have an adequate level of confidence that is relevant, competent, sufficient and material.

c. Reporting on Audit Results (7 days)

1) The Team Leader drafts the Audit Result Report (LHA).

2) The LHA concept is reviewed and corrected by the Technical Controller.

3) If the LHA concept is not corrected by the Technical Controller, then the concept is forwarded to the inspector for approval. If the LHA concept is corrected by the Technical Controller, the Team Leader will return the concept to be refined according to the results of the correction.

4) The corrected LHA concept which has been reviewed by the Technical Controller is submitted to the Inspector for approval.

5) The LHA concept that has been approved by the Inspector is returned to the Team Leader through the Technical Controller for a final LHA. If the LHA concept has not been approved by the Inspector then the concept is returned to the Team Leader through the Technical Controller.

6) Final LHA is submitted to the technical controller for initialization and forwarded to the LIPI Inspector for signing.

7) The signed LHA is submitted to the Head of Sub-Section of Administration for duplication and distribution to the parties concerned.

d. LHA follow-up monitoring (3 days)

Follow-up monitoring is limited to reviewing or reviewing corrective actions that have been or are being carried out by the object of the examination of the audit findings recommendations, including comparing them with suggested or recommended actions.

LHA follow-up monitoring stages:

1) Auditor submits follow-up documents to the Audit Team.

2) The Audit Team conducts a review / review of the follow-up documents submitted by the Auditi.

3) If the results of the review from the Audit Team are deemed complete, the follow-up document will be signed by the Audit Team and submitted to the LHA Follow-up Team.

Submitted: September 12, 2020; Accepted: September 12, 2020; Revised: December 12, 2020; Published: April 24, 2021; Website: http://journalfeb.unla.ac.id/index.php/jasa 


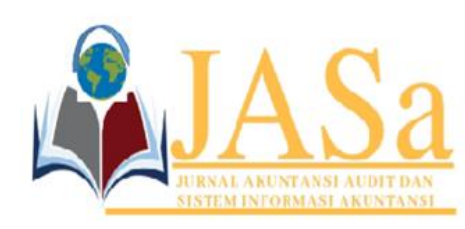

\author{
JASa (Jurnal Akuntansi, Audit dan Sistem Informasi Akuntansi) \\ Vol. 5 No.1/ April 2021 \\ ISSN 2550-0732 print / ISSN 2655-8319 online \\ DOI;10.36555/jasa.v5i1.1511
}

4) If the results of the review from the Audit Team contain things that need to be completed, the follow-up documents are returned to the Auditi to be completed and after that they are returned to the Audit Team.

The problem that occurs is that the audit is still carried out manually and has not been well systemized and documented electronically, starting from the planning of the audit, the appointment of the audit team, the implementation of the audit, the audit reporting, to the monitoring of the audit reports, thus causing the audit activity documents so far not documented neatly in one database system. In addition, in terms of collecting and analyzing audit evidence, auditors still analyze a lot of data or physical documents in paper, which are in large quantities, so they require a longer examination time. The auditor has not maximally utilized electronic data or documents for examination purposes, which in fact can already be accessed through SPBE applications that have been implemented. The lack of utilization of data generated by SPBE for the purposes of this audit is one of the factors is that auditors must access data one by one from the number of SPBE applications available and also from some auditors who do not have the skills to operate these SPBE applications.

In an effort to improve the internal audit implementation system at the Inspectorate and make it easier for auditors to utilize SPBE electronic data for audit implementation, an electronic audit system (e-audit) is needed that can be integrated with other existing electronic-based government systems.

Refers to the FAST method in analyzing and designing a

system, then the following are the results of the design of the SPBE integrated e-audit system within the APIP / Inspectorate:

\title{
Scope Definition
}

The e-Audit system which is designed is an information system that has the ability to record the entire audit process into electronic data, from the audit planning stage to the follow-up monitoring stage of audit reports and is able to be integrated with other SPBE applications. The scope of this e-audit system can be illustrated in the system scope analysis table using the PIECES framework (Performance, Information, Economic, Control, Efficiency, Services) as in table 1.

Table 1. PIECES Analysis Table

\begin{tabular}{lll}
\hline No & Problems & Solutions \\
\hline & & Performance $(P)$
\end{tabular}

Performance $(P)$

1 The implementation of audit activities is The E-audit system is designed to still carried out manually, starting from the accommodate the storage of audit activity audit planning process, conducting data from the planning, implementation, audits, audit reporting, and monitoring the reporting, and monitoring stages of LHAs follow-up to the Audit Results Report into a centralized database.

(LHA), there is no audit management system so that the documentation of audit activities is not well documented

Submitted: September 12, 2020; Accepted: September 12, 2020; Revised: December 12, 2020; Published: April 24, 2021; Website: http://journalfeb.unla.ac.id/index.php/iasa 


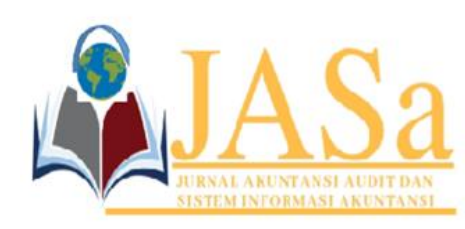

\author{
JASa (Jurnal Akuntansi, Audit dan Sistem Informasi Akuntansi) \\ Vol. 5 No.1/ April 2021 \\ ISSN 2550-0732 print / ISSN 2655-8319 online \\ DOI;10.36555/jasa.v5i1.1511
}

2 The collection and analysis of audit The E-Audit system allows each auditee evidence data, most of the auditors still to upload audit evidence in digital form refer to physical documents (paper), required by the Auditor in the audit causing the time needed for the audit to process

be longer.

3 The number of SPBE applications that The E-Audit system makes it possible to have been implemented but have not integrate data generated by other been well optimized in supporting audit systems, in this case SPBE. so that activities is due to not being integrated, auditors can access and analyze data only and the difficulty of auditors to access and from the e-audit system, without having to operate the existing SPBE applications access one-by-one the SPBE application one by one

\title{
Information (I)
}

1 Information on the historical data on audit The e-Audit system is built with a implementation, documentation of audit centralized and integrated database working papers from each auditor is approach, so it will make it easier for difficult to trace, and follow-up data from information to be presented quickly

audits on LHA is still not well documented, still manual scattered in several different files

2 Information related to electronic data The e-audit system is built with a service generated from SPBE to support audit oriented architecture (SOA) approach with activities is not easy to obtain, auditors the use of API (Application Programming must obtain it manually asking each Interface) technology so that it is able to person in charge of the SPBE application extract information generated by other to be printed. systems in only one e-Audit system.

\section{Economics (E)}

1 The length of implementation of the audit With the ease of the E-Audit system that is guided by the existing Audit SOP, is designed, it is hoped that it will reduce requiring 21 days of assignment the days for conducting the audit, in particular the number of days used to analyze audit evidence documents and the time for collecting audit data from the auditee, so that it is expected to be more economical.

2 Execution of audits with an ongoing E-Audit is designed so that audit system, produces physical documents documents do not have to be printed on that still have to be printed on paper and paper but rather in digital form, e-audit is duplicated in large quantities to be designed in a paperless spirit so that it will submitted to interested parties. be more economical

\section{Control (C)}

1 Performing audits that are still carried out E-audit is designed with an authentication manually so as to produce audit and authorization system, so only certain documents separately in each file, has a parties are given permission to be able to 


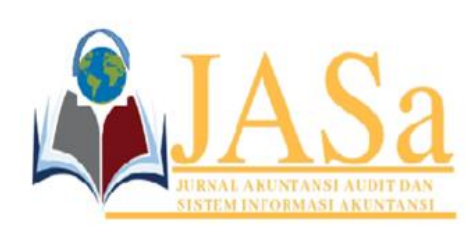

\author{
JASa (Jurnal Akuntansi, Audit dan Sistem Informasi Akuntansi) \\ Vol. 5 No.1/ April 2021 \\ ISSN 2550-0732 print / ISSN 2655-8319 online \\ DOI;10.36555/jasa.v5i1.1511
}

vulnerability if the data can be spread to access digital data / documents that are in unauthorized parties, or allow the the e-audit system

document to be lost.

2 Information documents obtained from The e-Audit system in retrieving data from other information systems are other systems (SPBE) is designed using confidential in nature because they may API technology so that data is sent directly be accidentally distributed to end to end between systems, so data will unauthorized parties so that they can be be safer

misused.

\title{
Efficiency (E)
}

1 In collecting audit documents, because E-audit is designed to allow audit they are still in the form of piles of physical documents to be collected in digital form paper documents, sometimes they still experience problems, which are late being collected by the auditee

2 Sometimes many confirmations are done face-to-face, so you have to make a meeting time with the party to be asked for information.

-audits are designed to enable a digita confirmation system, and conversation information can be recorded and documented in the system

\section{Services (S)}

1 The Audit Report is submitted in printed The E-Audit system allows the Auditi and document form and given to the auditee the Inspector as the person in charge to after the Audit process is completed be able to monitor the progress of the audit activities that are being carried out by the team

2 It is difficult to obtain audit implementation The E-Audit system is designed to documents (by auditors or interested document all audit activities into a parties) from each year, because they are centralized database, so that whenever still not integrated into one system. and wherever audit documents are needed, it will be easy to obtain.

Source : The results of the analysis from the author (2020)

\section{Problem Analysis}

At this stage the researcher analyzes the problems that occur and tries to provide a solution. The following are some of the problems contained in the implementation of the audit at the LIPI Inspectorate:

a) Audit activity documents have not been well managed, including audit planning documents, audit implementation documents (audit work papers, confirmation reports to auditors, documents attached to other audit work papers), Audit Report Reports, and Monitoring follow-up documents on reports Audit results submitted by the auditee. So it is difficult when there is a need to see historical documents of audit activities from previous years.

Submitted: September 12, 2020; Accepted: September 12, 2020; Revised: December 12, 2020; Published: April 24, 2021; Website: http://journalfeb.unla.ac.id/index.php/jasa 


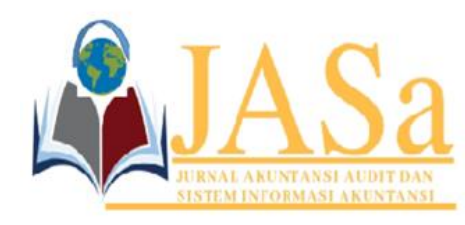

\author{
JASa (Jurnal Akuntansi, Audit dan Sistem Informasi Akuntansi) \\ Vol. 5 No.1/ April 2021 \\ ISSN 2550-0732 print / ISSN 2655-8319 online \\ DOI;10.36555/jasa.v5i1.1511
}

b) The method of collecting audit evidence documents still uses paper-based documents, so it requires a lot of time in the process of analysis and collection. This also causes audit activities to be carried out at the auditee location and remote audits cannot be carried out (remote audits). This does not answer the needs of today's challenges, where work can be done from anywhere and anytime.

c) There is no system capable of integrating data from other systems (SPBE). So that the auditors must access one by one to obtain audit evidence from the SPBE application or ask the person in charge of each application at the auditee to print the data, this is considered to be troublesome and less efficient.

Of the three main problems above, a solution can be proposed that the implementation of audits at the LIPI Inspectorate must be transformed into an audit by utilizing information technology, namely by building an e-Audit system which can accommodate the need for document management of audit implementation from the planning stage to follow-up monitoring. report on audit results, as well as being able to integrate data generated by other systems (SPBE) that can be used as audit evidence.

\title{
Requirements Analysis
}

After being able to describe some of the problems found and also formulating a solution, the next step is to analyze the needs of the e-audit system to be built. The SPBE integrated e-Audit system is expected to be able to assist the implementation of audits in the APIP / Inspectorate environment so that it is more neatly documented, effective and efficient, therefore the e-Audit system to be built must have several features such as the following:

a) The e-Audit system is able to record audit planning data, including PKPT (Annual Supervision Work Program) data, auditor profile data, auditor team data assigned to conduct audits including the composition of the team itself such as Technical Controllers, Team Leaders, and Team Members.

b) The e-Audit system is able to record audit data and organizational documents.

c) The e-Audit system is able to record data at the audit implementation stage, including: recording the activities and duties of each auditor every day (log activity), each auditor's audit working paper, confirmation / clarification minutes made by the auditor at the time examination.

d) In the e-Audit system, auditors can upload digital responsibility documents as audit evidence online.

e) The e-Audit system is able to document the Audit Result Reports electronically which can be accessed by various interested parties online.

f) The e-Audit system is able to provide a follow-up monitoring feature on the audit report that has been carried out, recording the progress of the follow-up carried out by the auditee.

g) To make it easier for auditors to collect and analyze audit evidence, the e-Audit system is built with features that can be integrated / connected with various SPBE application systems that have been implemented by the auditee, for example the Work Unit Application System, Payroll System, Performance Allowance Payment System and money employee meals, Official Travel System, E-Attendance Application, Non-Tax

Submitted: September 12, 2020; Accepted: September 12, 2020; Revised: December 12, 2020; Published: April 24, 2021; Website: http://journalfeb.unla.ac.id/index.php/jasa 


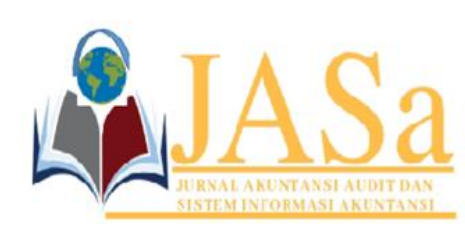

\section{JASa (Jurnal Akuntansi, Audit dan Sistem Informasi Akuntansi) \\ Vol. 5 No.1/ April 2021 \\ ISSN 2550-0732 print / ISSN 2655-8319 online \\ DOI;10.36555/jasa.v5i1.1511}

Revenue System (SIMPONI), e-Planning System (KRISNA), e-Budgetting System (RKA $K / L$ Online), e-Procurement System (SPSE), Government Agency Accounting System ( e-REKON \& LK).

\section{Logical Design}

At this logical design stage, what is done is how to change the various business needs that have been identified in the previous needs analysis phase into a system model. Changing from business needs that have been described descriptively using words into the form of images is called a model system.

In this e-audit system research, the model system is designed using Data Flow Diagrams (DFD) and Entity Relationship Diagrams (ERD).

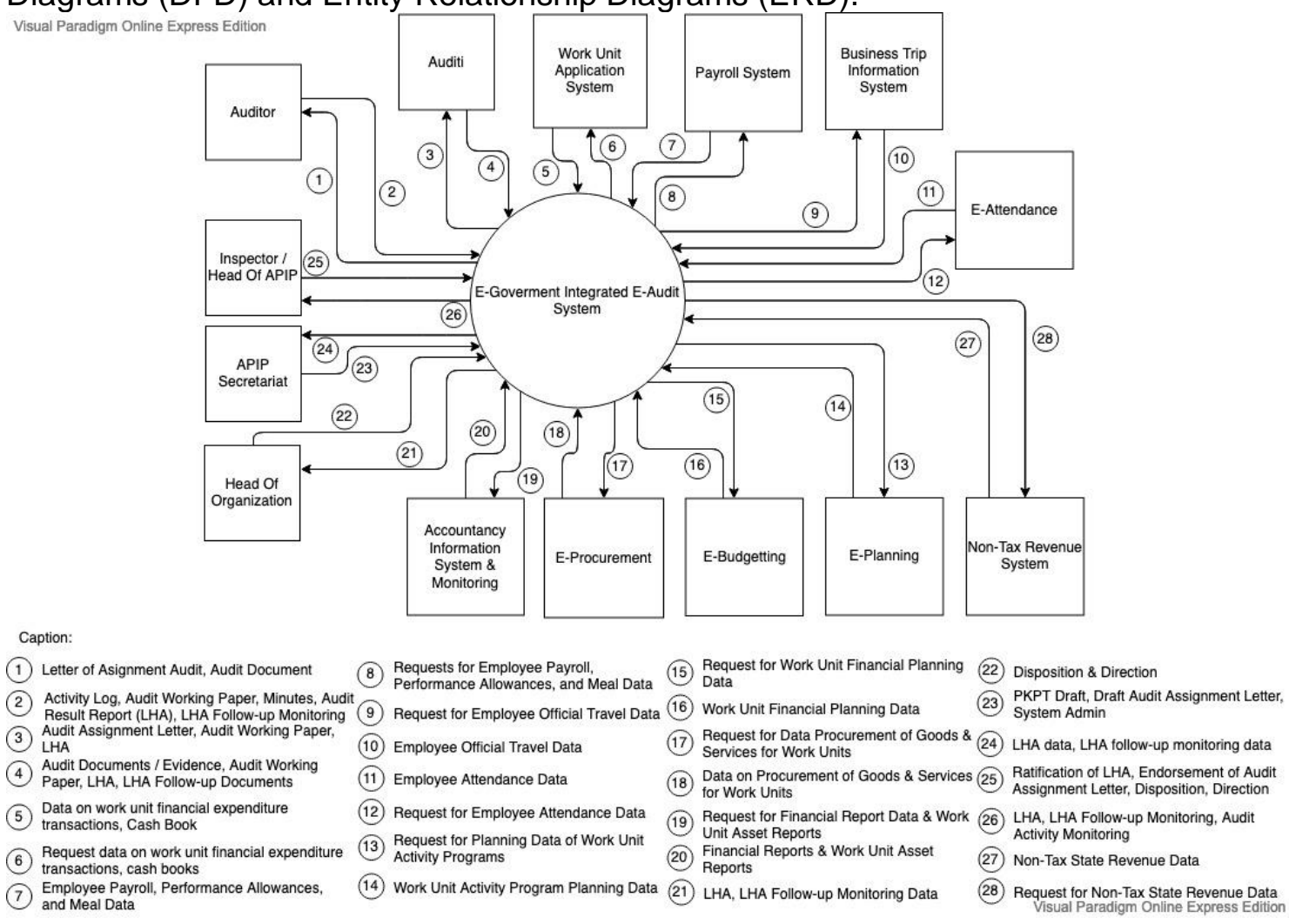

Figure 2. Context Diagram of E-Government integrated e-Audit system

Submitted: September 12, 2020; Accepted: September 12, 2020; Revised: December 12, 2020; Published: April 24, 2021; Website: http://journalfeb.unla.ac.id/index.php/jasa 


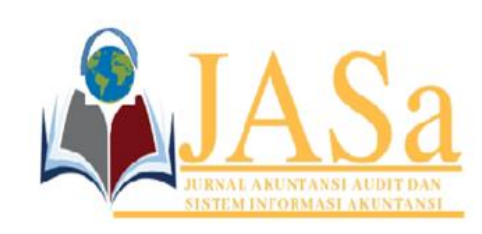

JASa (Jurnal Akuntansi, Audit dan Sistem Informasi Akuntansi)

Vol. 5 No.1/ April 2021

ISSN 2550-0732 print / ISSN 2655-8319 online

DOI;10.36555/jasa.v5i1.1511
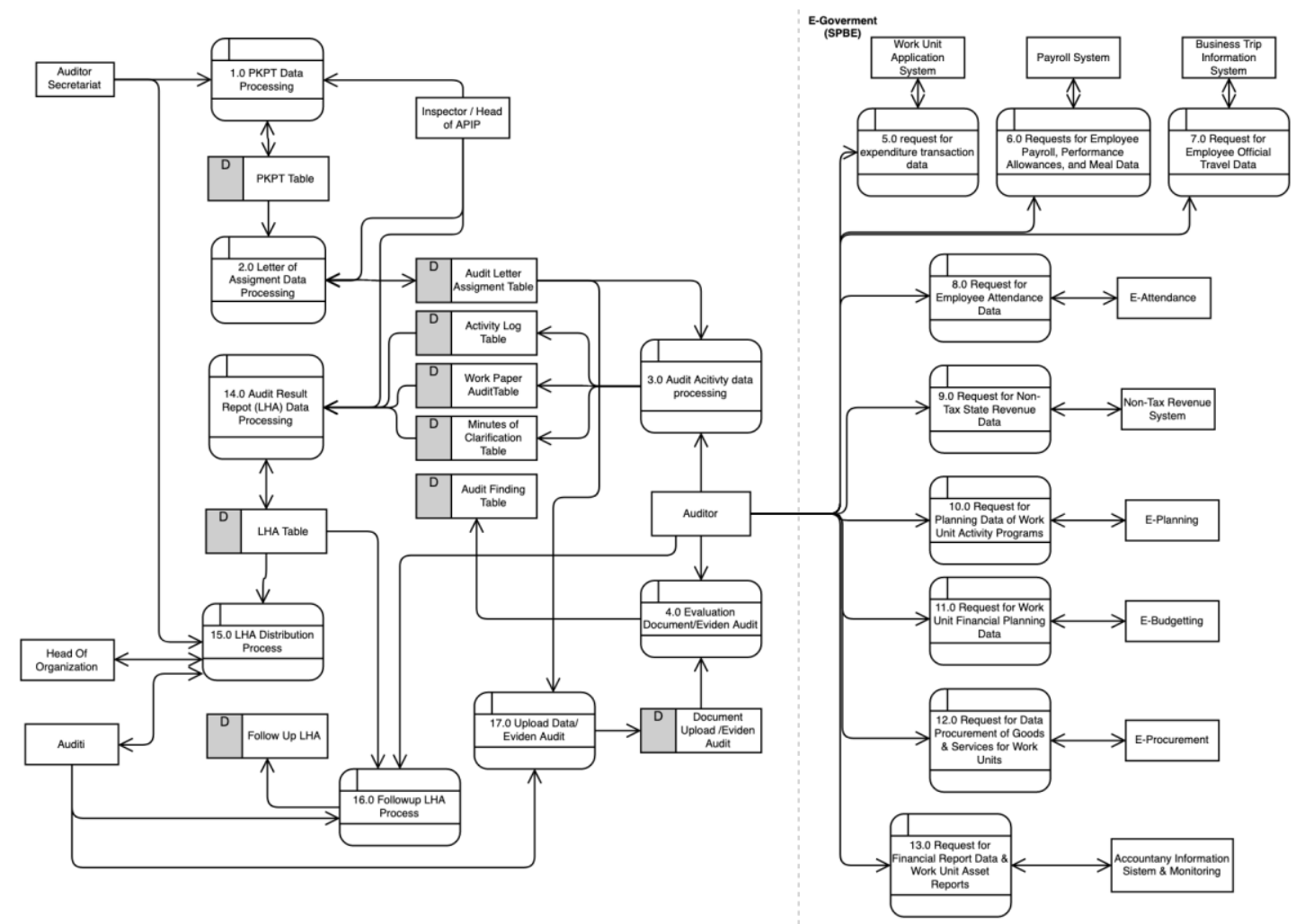

Figure 3. Data Flow Diagram Level 0 SPBE integrated e-Audit system 


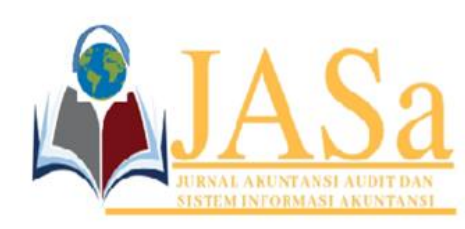

JASa (Jurnal Akuntansi, Audit dan Sistem Informasi Akuntansi)

Vol. 5 No.1/ April 2021

ISSN 2550-0732 print / ISSN 2655-8319 online

DOI;10.36555/jasa.v5i1.1511

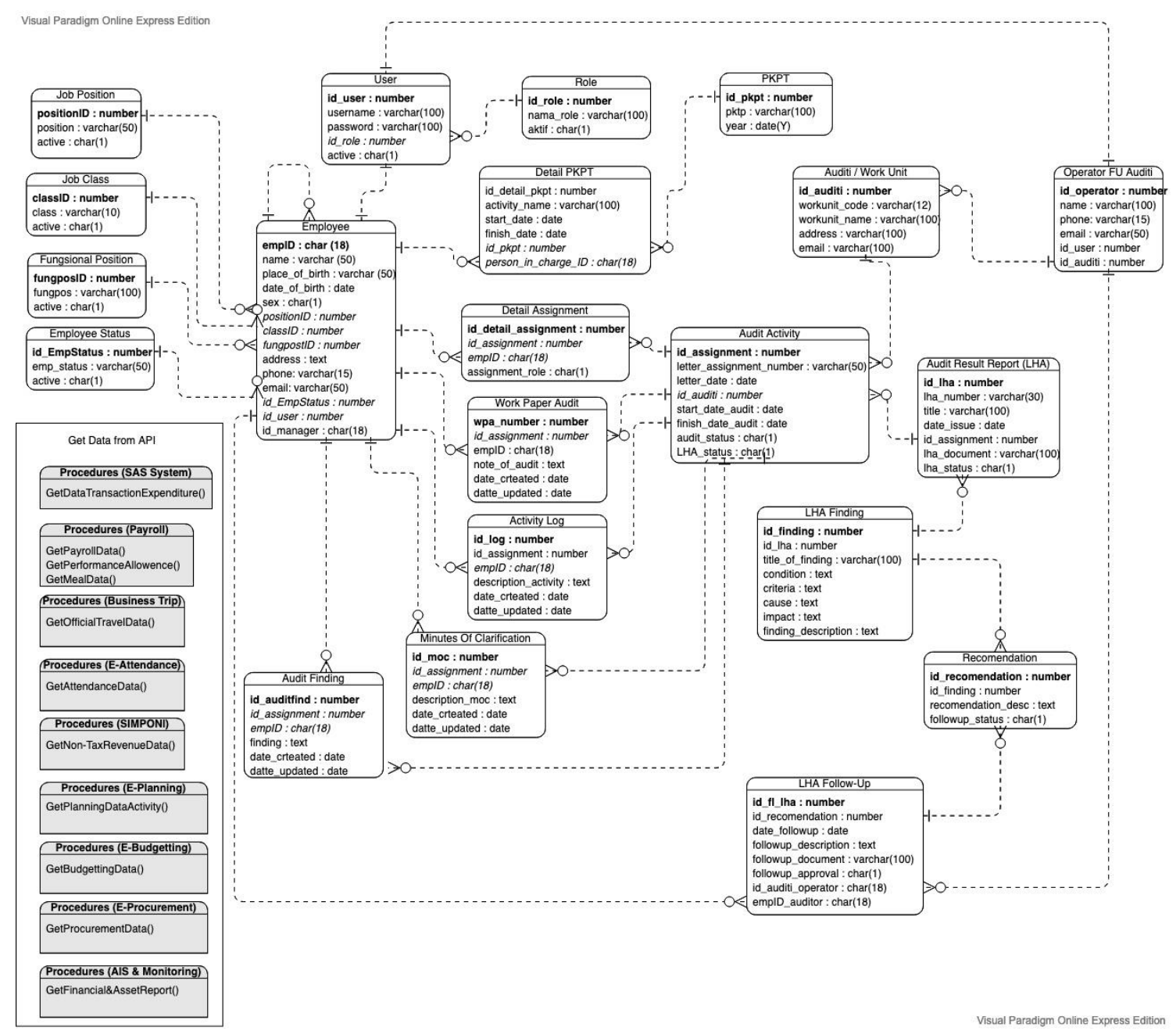

Figure 4. Entity Relationship Diagram (ERD) E-Audit System

\section{CONCLUSION}

The development of technology and information has changed the way an organization / institution works, working that was previously done with manual systems is encouraged to be converted into an electronic-based system. The process of digitizing this system does not only occur in the private sector, but also in the government sector, this digitization process is being pushed to continue to be realized. The increasing use of the Electronic-Based Government System (SPBE) ultimately has an impact on the form of documents or data produced, which were previously in physical form or in the form of paper documents, now turning into data in the form of digital documents or information. Therefore, the implementation of this SPBE also affects the audit implementation process carried out by the Government Internal Supervisory Unit (APIP). APIP, which has been performing manual audits so far, uses a lot of documents or

Submitted: September 12, 2020; Accepted: September 12, 2020; Revised: December 12, 2020; Published: April 24, 2021; Website: http://journalfeb.unla.ac.id/index.php/jasa 


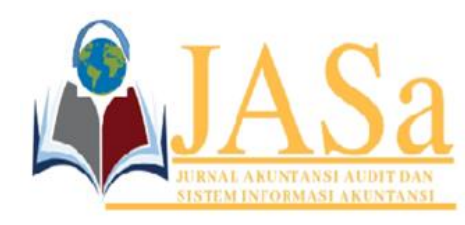

\author{
JASa (Jurnal Akuntansi, Audit dan Sistem Informasi Akuntansi) \\ Vol. 5 No.1/ April 2021 \\ ISSN 2550-0732 print / ISSN 2655-8319 online \\ DOI;10.36555/jasa.v5i1.1511
}

physical / paper data, must have started to change its method to an electronic databased audit system or called e-Audit. However, the next problem is that the current SPBE operates separately, causing auditors in collecting data to be not effective enough.

In this study, researchers designed an e-audit system model with a case study research method in one of the inspectorates in a non-ministerial government agency. This e-audit system is designed to have a function as an electronic-based audit management system and is also designed to be integrated with several SPBE that have been implemented by the government or internal organizations. The design of this e-audit system was built using the FAST framework with a scope of 4 design stages (Scope Definition, Problem Analysis, Requirement Analysis, and Logical Design). The result of this research is an integrated e-audit system model SPBE which is manifested in the form of a Context Diagram, Data Flow Diagram (DFD) and in the form of an Entity Relationship Diagram (ERD).

The use of information technology/ computers in assisting the implementation of audits has long been the subject of research in the field of auditing, in this research the problem limitation that is built is that the e-audit system is designed to assist post audit activities (audits that are carried out after the organization / company activities are completed), for future research an e-audit system can be designed that is built with realtime data or what is often called Continuous Auditing (CA). This CA is very interesting to conduct research because with the change in the role of an internal auditor who was previously only a watchdog, now it has changed its role to become a consultant and catalyst.

\title{
REFERENCES
}

American Institute of Certified Public Accountants. (2001). Effect of information technology on the auditor's consideration of internal control in a financial statement audit; Statement on auditing standards, 094.

Arens, A. A and Loebecke, J.K. yang diterjemahkan oleh Jusuf, A.A, (1997). Auditing Pendekatan Terpadu, buku 1 (Edisi Indonesia). Salemba Empat, Jakarta.

Department of Economic and Social Affairs. (2020). 2020 United Nations E-Government Survey.

Gondodiyoto, Sanyoto (2003). Audit Sistem Informasi Pendekatan Konsep. PT. Media Global Edukasi (McGraw-Hill Education), Jakarta.

Peraturan Pemerintah No.60 Tahun 2008 tentang Sistem Pengendalian Intern Pemerintah, Pub. L. No. 60 (2008).

Peraturan Presiden Nomor 95 Tahun 2018 tentang Sistem Pemerintahan Berbasis Elektronik, Media Hukum 110 (2018).

Karimah, N. (2018). Implementasi Sistem Electronic Audit Berdasarkan Aspek Persepsi Keguanaan Dan Kemudahan Pengguna Di Pemerintah Provinsi Sulawesi Barat. Universitas Islam Alaudin.

Kristian, M., \& Imelda, E. (2017). Analisis Faktor Yang Mempengaruhi Pelaksanaan Audit Berbasis Teknologi Informasi. Jurnal Akuntansi, 19(2), 295. https://doi.org/10.24912/ja.v19i2.100 


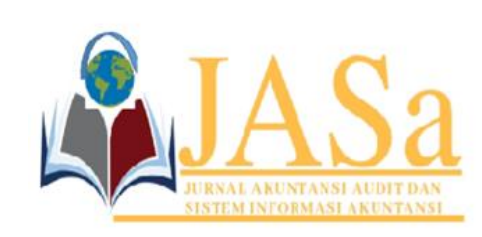

\section{JASa (Jurnal Akuntansi, Audit dan Sistem Informasi Akuntansi) \\ Vol. 5 No.1/ April 2021 \\ ISSN 2550-0732 print / ISSN 2655-8319 online \\ DOI;10.36555/jasa.v5i1.1511}

Mulyadi. (2002). Auditing. Edisi ke-6. Salemba Empat, Jakarta.

Redhat. (2020). What is an API? https://www.redhat.com/en/topics/api/what-areapplication-programming-interfaces

Sekaran, U., \& dan Bougie, R. (2010). Research method for business: A skill builcling approach (Edisi 5). New York: John Wiley.

Siti Mubiroh, (2019). Analisis Implementasi E-audit untuk Pemeriksaan Keuangan Negara Studi pada BPK RI Perwakilan Daerah Istimewa Yogyakarta, Berkala Akuntansi dan Keuangan Indonesia, Vol.04, No.01 (2019), 15-34.

Tarippudin, A. (2014). Kualitas Dan Efisiensi Pemeriksaan: Studi Pada Implementasi Piloting Project E-Audit Di Badan Pemeriksa Keuangan Republik Indonesia. Universitas Sebelas Maret.

Whitten, J. L., \& dan Bentley, L. D. (2007). System analysis and design methods (7th Edition). New York: The McGrow-Hill Company 